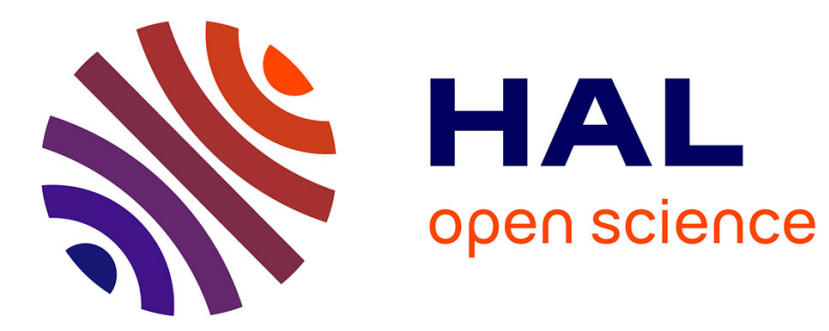

\title{
Solar and proxy-sensitivity imprints on paleohydrological records for the last millennium in west-central Europe
}

\author{
Michel Magny, Fabien Arnaud, H. Holzhauser, Emmanuel Chapron, Maxime
}

Debret, Marc Desmet, A. Leroux, Marie Revel, Boris Vannière, Laurent Millet

\section{- To cite this version:}

Michel Magny, Fabien Arnaud, H. Holzhauser, Emmanuel Chapron, Maxime Debret, et al.. Solar and proxy-sensitivity imprints on paleohydrological records for the last millennium in west-central Europe. Quaternary Research, 2010, 73 (2), pp.173-179. 10.1016/j.yqres.2009.11.006 . insu-00446080

\section{HAL Id: insu-00446080 \\ https://hal-insu.archives-ouvertes.fr/insu-00446080}

Submitted on 25 Oct 2011

HAL is a multi-disciplinary open access archive for the deposit and dissemination of scientific research documents, whether they are published or not. The documents may come from teaching and research institutions in France or abroad, or from public or private research centers.
L'archive ouverte pluridisciplinaire HAL, est destinée au dépôt et à la diffusion de documents scientifiques de niveau recherche, publiés ou non, émanant des établissements d'enseignement et de recherche français ou étrangers, des laboratoires publics ou privés. 
Solar and proxy-sensitivity imprints on paleohydrological records for the last millennium in west-central Europe

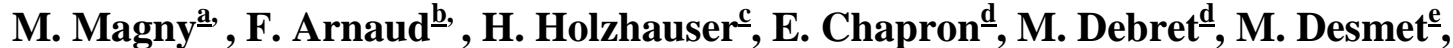 A. Leroux ${ }^{\mathbf{a}}$, L. Millet ${ }^{\mathrm{a}}$, M. Revel $^{\mathbf{f}}$ B. Vannière ${ }^{\mathrm{a}}$
}

a CNRS-UMR 6249, Laboratoire de Chrono-Environnement, Faculté des Sciences, et Techniques, 16 route de Gray, 25030 Besançon, France

b Environnement Dynamique et Territoires de la Montagne, Université de Savoie, CNRS, Pôle Montagne, Technolac, 73373 Le Bourget du Lac, France

${ }^{c}$ Ahornstrasse 38, 8051 Zürich, Switzerland

d Institut des Sciences de la Terre d'Orléans, UMR 6113 CNRS-Université d'Orléans, 1A rue de la Ferollerie, 45071 Orléans cedex O2, France

e ACCES-INRP, 19 Allée de Fontenay, BP 17424, 69347 Lyon Cedex O7, France

f Geosciences Azur, La Darse BP 48, 06235

Villefranche/Mer, France

\begin{abstract}
This paper presents a lake-level record established for the last millennium at Lake Saint-Point in the French Jura Mountains. A comparison of this lake-level record with a solar irradiance record supports the hypothesis of a solar forcing of variations in the hydrological cycle linked to climatic oscillations over the last millennium in west-central Europe, with higher lake levels during the solar minimums of Oort (around AD 1060), Wolf (around AD 1320), Spörer (around AD 1450), Maunder (around AD 1690), and Dalton (around AD 1820). Further comparisons of the Saint-Point record with the fluctuations of the Great Aletsch Glacier (Swiss Alps) and a record of Rhône River floods from Lake Bourget (French Alps) give evidence of possible imprints of proxy sensitivity on reconstructed paleohydrological records. In particular, the Great Aletsch record shows an increasing glacier mass from AD 1350 to 1850, suggesting a cumulative effect of the Little Ice Age cooling and/or a possible reflection of a millennial-scale general cooling until the mid-19th century in the Northern Hemisphere. In contrast, the Saint-Point and Bourget records show a general trend toward a decrease in lake levels and in flood magnitude anti-correlated with generally increasing solar irradiance.
\end{abstract}

Keywords: Lake levels; River discharge; Glacier fluctuations; Last millennium; Solar forcing; Jura Mountains; Central; NW Alps

\section{Introduction}

The perspective of a global warming scenario has provoked an increasing interest in studies of climate variability over the last millennium. They preferentially document past changes in temperature ( [Mann et al., 1999] , [Mann et al., 2008] , [Crowley, 2000] , [Jones et al., 2001] , [Guiot et al., 2005] and [Moberg et al., 2005] ). However, the reconstruction of changes in the hydrological cycle associated with climatic oscillations and with relationships concerning availability of water resources is a scientific key question for the paleoclimatologist community (Vörösmarty et al., 2000). 
As a contribution to such studies, this paper presents a new paleohydrological record for the last millennium based on the reconstruction of changes in lake level at Lake Saint-Point in the French Jura Mountains. This record offers the opportunity to test hypotheses about the possible driving factors behind regional paleohydrological variability during this period (Magny et al., 2008), while inter-regional comparisons with other paleohydrological records point to other possible imprints on records such as proxy sensitivity and/or complex interactions between precipitation and temperature.

\section{Site and methods}

Lake Saint-Point $\left(46^{\circ} 48^{\prime} \mathrm{N}, 6^{\circ} 12^{\prime} \mathrm{E}\right)$ is a $7.6-\mathrm{km}$-long narrow and overdeepened basin of glacial origin. The present water depth reaches $41 \mathrm{~m}$ and the lake area is $7 \mathrm{~km}^{2}$. It is located at an altitude of $850 \mathrm{~m}$ a.s.l. in the highest part of the French Jura Mountains (Fig. 1). The surrounding mountains attain ca. $1450 \mathrm{~m}$ a.s.l. The catchment area of the lake covers ca. 247 $\mathrm{km}^{2}$. The substratum mainly comprises Upper Jurassic and Tertiary limestones (Leroux et al., 2008).

The main inlet (as well as the outlet) of the lake is the Doubs River. The seasonal fluctuations of the water table are characterized by maximal levels most often due to autumn rains and spring snowmelt, while minimal levels result from summer droughts ( [Magnin, 1904] and [2] ). The Lake Saint-Point region is marked by relatively severe semi-continental climatic conditions. At lake altitude, mean annual precipitation attains ca. 1500 to $1900 \mathrm{~mm}$, mean annual temperature ca. $10.2^{\circ} \mathrm{C}\left(2.7^{\circ} \mathrm{C}\right.$ in the coldest month, and $21.3^{\circ} \mathrm{C}$ in the warmest month). During severe winters, the lake surface may remain frozen for several successive weeks.

The coring site is located in a littoral mire, close to the southwestern lake shore (Fig. 1). After establishing a core transect perpendicular to the shore by means of a Russian peat corer, a core (labeled core 7) was taken for lake-level studies on a site where the sediment sequence shows an alternation of peat and carbonate layers characteristic of past changes in lake level. While previous studies of Lake Saint-Point sediment sequences focused on the early and midHolocene (Magny and Ruffaldi, 1995), the present paper deals with the late Holocene as documented by the upper part of the core 7 sedimentary sequence.

The lake-level fluctuations were reconstructed using a specific sedimentological method ( [Magny, 1998] and [Magny, 2006] ), based on multiple lines of evidence, including changes in the lithology (organic versus carbonate deposits) and the relative frequency of various carbonate concretion morphotypes of biochemical origin. Modern analogue studies have given evidence that each morphotype shows a specific spatial distribution from the shore to the extremity of the littoral platform, with the successive domination of oncolites (nearshore areas with shallow water and high energy environment), cauliflower-like forms (littoral platform), plate-like concretions (encrustations of leaves from the Potamogetonion and Nymphaeion belts), and finally tube-like concretions (stem encrustations from the Characeae belt on the platform slope; [Magny, 1998] and [Magny, 2006] ). In addition to variations in the assemblages of carbonate concretions, the relative frequency of plant macro-remains provides further information about the deposition environment. Thus, abundance of vegetal remains partly inherited from littoral vegetation (particularly ligneous vegetal remains) increases toward the shore. 
The chronology is based on five radiocarbon dates (Table 1). Ages have been calibrated using Calib 5.1 ( [Stuiver et al., 1998] and [Reimer, 2004] ). Probably due to reworked material, level $47 \mathrm{~cm}$ provided an inconsistent age of $6900 \pm 40{ }^{14} \mathrm{C}$ yr BP (Fig. 2). Level $111 \mathrm{~cm}$ appears to be dated to $3315 \pm 30{ }^{14} \mathrm{C}$ yr BP (i.e., $3631-3471$ cal yr BP at $2 \sigma$ range), in agreement with pollen data obtained in previous studies (Magny and Ruffaldi, 1995). This suggests that the organic layer at level 110-112 cm, embedded between two distinct white and yellow-beige layers of carbonate lake marl, corresponds to a sediment hiatus. Figure 2 shows the age-depth model established for the upper part of Saint-Point core 7, taking into account the maximum probability intervals at $2 \sigma$ range. It indicates that, based on the upper part of core 7 above level $110 \mathrm{~cm}$, the lake-level studies presented in this paper document the last millennium with a mean temporal resolution of ca. $50 \mathrm{yr} / 5-\mathrm{cm}$-thick sample.

\section{Results}

Figure 3 shows the sediment diagram established for the upper part of the sediment sequence of Saint-Point core 7, above level $110 \mathrm{~cm}$. One may observe that the carbonate lake-marl layers of this sediment sequence are generally characterized by a relatively high representation of oncolites, while the percentages of tube and plate concretions remain at a low level. This suggests that, even during the phases of higher lake-level conditions marked by the deposition of carbonate lake marl, the coring site remained close to the shore (eulittoral zone). In general, the representation of oncolites appears to be anti-correlated with that of ligneous vegetal remains. Hence, on the right of the sediment diagram, a curve of relative changes in lake level is shown as reflected by the ratio between the total scores (i.e., percentages of representation) of markers indicating lower lake-level conditions (i.e., vegetal remains) and those indicating higher lake-level conditions with a sedimentation in open water (i.e., carbonate concretions; [Magny, 1998] and [Magny, 2006] ; see also Site and methods above). In addition, the curve of lithoclasts appears to mimic that of oncolites, with peaks in the carbonate lake-marl layers. Given that the coring site is closed to the inlet of the Doubs River, this suggests that a higher frequency of lithoclasts probably reflects increasing water discharge and clastic input into the lake by the Doubs. The curve of relative changes in lake level highlights eight successive phases of high and low water table as follows:

- Phase 1 developed before $840 \pm 30{ }^{14} \mathrm{C}$ yr BP and was characterized by a relatively high lake level marked by the deposition of a carbonate lake-marl layer.

- Phase 2 corresponded to low lake-level conditions around $840 \pm 30{ }^{14} \mathrm{C} \mathrm{yr} \mathrm{BP}$. Such conditions favored the deposition of a peaty layer (peak of ligneous vegetal remains).

-After $840 \pm 30{ }^{14} \mathrm{C}$ yr BP, Phase 3 coincided with a marked rise in lake level as indicated by the development of concretions and the concomitant strong retreat of ligneous vegetal components. The frequency of lithoclasts also increases with maximal values over $20 \%$. At level $72 \mathrm{~cm}$, a decline in oncolites and lithoclasts as well as an increase in non-ligneous vegetal remains mark an intermediate lowering dated to $350 \pm 30{ }^{14} \mathrm{C} \mathrm{yr} \mathrm{BP}$.

- Phase 4 was characterized by lower lake-level conditions that provoked a return to the deposition of organic sediments (peak of ligneous vegetal remains).

- Phase 5 corresponded to higher lake-level conditions reflected by a peak of oncolites in addition to the presence of cauliflower, plate and tube concretions. 
- During Phase 6 (ca. $245 \pm 30{ }^{14} \mathrm{C}$ yr BP), low lake-level conditions prevailed, as shown by an increase in the representation of vegetal remains and the quasi-disappearance of carbonate concretions (deposition of a peaty layer).

-After $245 \pm 30{ }^{14} \mathrm{C}$ yr BP, Phase 7 coincided with higher lake-level conditions responsible for the deposition of a carbonate lake-marl layer. In addition to a peak of oncolites, the representation of tube concretions reaches ca. $10 \%$.

-Finally, dated to ca. $117.27 \pm 0.38$ pMC (i.e., percent modern carbon), Phase 8 marks a lowering well illustrated by maximal values of the ligneous vegetal remains (peat layer). The accumulation of organic deposits in the 18-cm-thick superficial peat layer may reflect an impact of the recent regulation of the water table to avoid excessive lowstands during the tourist summer season.

\section{Discussion}

The Saint-Point lake-level record offers a new opportunity to test hypotheses on the possible forcing factors of paleohydrological changes associated with climate variations in westcentral Europe over the last millennium. The right panel of Figure 4 compares the Saint-Point record with the curve of variations in solar irradiance based on cosmogenic nuclides (Bard et al., 2000). Within the age uncertainties given by the radiocarbon dates (Table 1; Figure 2 and Figure 4, right panel), the Saint-Point record has been tuned to the solar irradiance record. Figure 4 (right panel) shows the radiocarbon age as well as the age uncertainty (maximum probability intervals at $2 \sigma$ range defined by calibration; see Table 1 and Fig. 2) of lake-level events used to tune the Saint-Point record to the solar irradiance record (Bard et al., 2000). The comparison of the two records suggests a possible general agreement between the lakelevel events reconstructed at Lake Saint-Point and variations in the solar activity. Highstands developed during the successive solar minimums of Oort at around AD 1060, Wolf at around AD 1320, Spörer at around AD 1450, Maunder at around AD 1690, and Dalton at around AD 1820.

Thus, the paleohydrological record of Lake Saint-Point supports the hypothesis of a possible solar forcing of climate as inferred from previous studies at Lake Joux in the Swiss Jura Mountains for the last millennium ( [Magny, 2004] and [Magny et al., 2008] ) or from various proxy records for the late Holocene in northwestern Europe ( [Mauquoy et al., 2002] and [Haltia-Hovi et al., 2006] ), in northeastern North America (Hughes et al., 2006), in the western North Atlantic Ocean (Lund and Curry, 2006), as well as in equatorial east Africa (Verschuren et al., 2000). Figure 4 also gives evidence that the periods of minimum water table at Lake Saint-Point, which were marked by the sedimentation of organic deposits, closely coincided with phases of stronger solar activity at around AD 1200 (Medieval Warm Period, i.e., MWP), AD 1630 and 1760 (i.e., just before and after the Maunder minimum), and since the late 19th century (recent warming).

To sum up, the early part of the millennium and the Little Ice Age (LIA) generally coincided with higher lake-level conditions, while the last part of the Medieval Warm Period (MWP) around ca. AD 1200 and the recent warming since the mid-19th century corresponded to lower water tables. Finally, considered as a whole, the solar irradiance and the Saint-Point lake-level records show anti-correlated general trend, with solar maximum and lake-level minimums at ca. AD 1200, a rapid decrease in solar irradiance and increase in lake levels 
from ca. AD 1200 to ca. AD 1450, followed by a general increase in solar irradiance and decrease in lake level until present time.

For further tests and comparisons with other west-central European paleohydrological records based on different types of proxies, Figure 4 presents the variations in size of the Great Aletsch Glacier in the Swiss Alps (Holzhauser et al., 2005) and the Titanium record established from core LDB 04-I at Lake Le Bourget in the French northern Pre-Alps ( [Arnaud et al., 2005] and [Jacob et al., 2008] ; Fig. 1). The Aletsch record (central panel of Fig. 4) benefits from a robust chronology based on tree-ring analysis of in situ subfossil trunks, in addition to archeological and historical pictorial data. As pointed out by Holzhauser et al. (2005), the behavior of mountain glaciers (advance or retreat) reflects the sum of complex interactions of climatic parameters (e.g., temperature and precipitation) and topographic conditions. Basically, they advance if temperatures decrease (particularly in summer) and/or precipitation increases. Moreover, it has been calculated that the response time of the Great Aletsch Glacier is an order of 50 to $100 \mathrm{yr}$ (Haeberli and Holzhauser, 2003).

Core LDB 04-I was taken at 100-m water depth in Lake Le Bourget, a fjord-type foreland lake of the French NW Pre-Alps, and which is a tributary of the Rhône River (Fig. 1). The Ti record reconstructed from core LDB 04-I (left panel of Fig. 4) gives evidence of major floods from the Rhône River, which enters the northern part of the lake through the lake outlet, and brings water discharge and clastic input in particular from high-elevated zones (catchment area of the Arve River in the French NW Alps, Mont Blanc massif; [Chapron et al., 2002] , [Arnaud et al., 2005] , [Revel-Rolland et al., 2005] and [Jacob et al., 2008] ). The chronology of this high-resolution $(<8 \mathrm{yr})$ continuous record is based on (1) the identification of the varve-count dated eutrophication of the lake at AD 1943 (Giguet-Covex et al., 2009), (2) the identification of flood deposits (underflows) related to historical floods after AD 1734 (Chapron et al., 1999), and (3) one radiocarbon date that yields an age of $1200 \pm 30 \mathrm{cal} \mathrm{yr}$ BP (i.e., AD 710-940 at $2 \sigma$ range). Hence, whereas the age uncertainty is $<10 \mathrm{yr}$ since the early 18th century, for the lower part of the Ti record presented in Figure 4, it is at least on an order of $\pm 100 \mathrm{yr}$ if the radiocarbon age calibration is taken into account.

On a general scale, similarities appear between the different types of records as follows. At ca. AD 1200, low lake levels in the Jura Mountains coincided with a Ti minimum at Lake Le Bourget and a retreat of the Great Aletsch Glacier. Between ca. AD 1300 and 1850, the LIA appears to be characterized by general conditions marked by wetter and cooler climate resulting in higher lake levels in the Jura Mountains, more frequent floods in the upper Rhône Valley. These general conditions may have favored an advance of the Aletsch Glacier (Holzhauser et al., 2005), while dry easterly atmospheric flow during the coldest periods of LIA may also have favored the preservation of Alpine glaciers. This general pattern for LIA is in agreement with the high level of summer and annual mean precipitation reconstructed by [Casty et al., 2005] and [Pauling et al., 2006] in the Alps from AD 1500 to AD 1700. The recent warming since $\mathrm{AD} 1850$ is marked by a concomitant lake-level lowering, a glacier retreat, and a decrease in river discharge (the latter has also been enhanced by anthropogenic embanking along the Rhône River since ca. AD 1870; Chapron et al., 2002). Before AD 1200, one observes a high lake-level phase in the Jura Mountains at ca. AD 1060, an advance of the Aletsch Glacier culminating at ca. AD 1100-1150, and a Ti peak at Lake Le Bourget at ca. AD 1160. Chronological discrepancies that appear between records before AD 1200 may be due to a longer response time of the Aletsch Glacier at the end of the MWP (which favored a marked retreat in higher elevation areas), and chronological uncertainties in the Le Bourget record as explained above. 
Dissimilarities also appear between the records presented in Figure 4. The Aletsch and Le Bourget records, which reflect changes in high-elevation areas, show river discharge and glacier maxima early in the LIA (at ca. AD 1300-1370), while in the lower elevation Jura Mountains, lake-level maxima culminated later at ca. AD 1450 (in agreement with the Spörer solar irradiance minimum). Such a strong early impact of the beginning LIA in NW Alps has also been observed from a chironomid-based temperature record at Lake Anterne (Millet et al., 2009). However, the Ti peak in the Le Bourget record around AD 1300 may also, at least in part, reflect a possible contribution of human impact at a crucial transition between the late medieval forest clearing and the beginning LIA. Such a hypothesis has been illustrated in Germany by extensive soil erosion due to a combination of human impact and heavy rainfall in the 14th century (Bork, 1989).

Furthermore, considering the general trend outlined by every record, it is noteworthy that the Le Bourget and Saint-Point records are characterized by a general decrease (in Rhone River floods and in lake level, respectively), anti-correlated with a general increase in solar irradiance from AD 1500 onward. In contrast, beyond three size-equivalent maxima at ca. AD 1370, 1670 and 1860, the less and less marked retreats of the Aletsch Glacier at ca. AD 1250, 1500 and 1750 suggest a cumulative effect of LIA cooling with an increasing mass of the glacier, before a rapid melting and retreat after AD 1850 (Fig. 4). As an alternative but not conflicting explanation, the pattern shown by the Aletsch Glacier record, which has equivalents elsewhere (see for instance in northern North America; Barclay et al., 2009), may also be a reflection of a millennial-scale general cooling until the mid-19th century reconstructed in the Northern Hemisphere ( [Mann et al., 1999] and [Solomon et al., 2007] ). This may suggest a relatively strong influence of the temperature parameter in addition to that of precipitation.

Finally, on a centennial scale, correspondences may be observed in the details between the solar irradiance record and (1) the Saint-Point lake-level record during the entire LIA, and (2) the detrital discharge record of the Rhône River after AD 1400. On the other hand, the Aletsch record shows correspondences with the solar irradiance record more particularly on a plurisecular scale, as pointed out by Holzhauser et al. (2005). This probably results from the fact that the Aletsch Glacier fluctuations reflect more complex interactions between climatic parameters, which result in this delayed reaction and response time.

\section{Conclusion}

The establishment of a new lake-level record at Lake Saint-Point confirms the regional paleohydrological pattern reconstructed for the last millennium in the Jura Mountains and characterized by generally higher lake-level conditions during the LIA. It also supports the hypothesis of a major solar forcing of climate and associated hydrological variations in this region during the last $1000 \mathrm{yr}$. This conclusion does not rule out the possible contribution of other factors such as volcanic forcing, for example around AD 1250-1300, 1450, 1600, 1700, and 1809-1830 ( [Zielinski, 2000] and [Castellano, 2005] ), or changes in Atlantic Ocean circulation (Lund and Curry, 2006). In addition, while an increasing literature (e.g., [De Vleeschouwer et al., 2009] and [Liu et al., 2009] ) suggests apparent correlations between sun and climate over the last millennia, recent papers also point to the fact that the amplitude of changes in solar activity was probably small (e.g., Krivova and Solanki, 2008). This calls for

further investigations before establishing a more comprehensive view of possible mechanisms behind such a sun-climate relation (e.g., [van Geel et al., 1999] , [Renssen et al., 2006] and [Meehl et al., 2009] ). 
The comparison of the Saint-Point lake-level record with the fluctuations of the Aletsch Glacier in the Swiss Alps and the record of detrital discharge in the upper Rhône River as reflected by a Ti record from Lake Le Bourget in the French NW Alps gives evidence of possible imprints of the type of proxy and/or site used to establish paleohydrological records. Both Le Bourget and Aletsch Glacier records suggest a particularly strong impact of the beginning LIA on high-elevation areas of the NW Alps, with a strong paleohydrological signal as early as AD 1300-1350. In addition, while the Lake Saint-Point and Le Bourget records after AD 1450 show a common general trend toward a decrease in lake level in the Jura Mountains as well as in floods in the upper Rhône Valley (in agreement with a general trend toward increasing solar irradiance), the Aletsch record suggests a cumulative effect of the LIA cooling marked by an increasing mass of the glacier until AD 1850, and/or a possible reflection of the general cooling trend of the Northern Hemisphere temperature during the LIA. Finally, on a centennial scale, the Aletsch record also shows differences from the SaintPoint and Le Bourget records. This points to a likelihood of more complex interactions between climatic parameters in the behavior of large glaciers such as the Aletsch Glacier, whereas both lake-level fluctuations and river-flood records are more directly linked to changes in hydrological conditions (precipitation).

\section{Acknowledgments}

Financial support for this study was provided by the French ANR (Project ESCARSEL supervised by J. Guiot) and CNRS (GDR 2992 "JurAlp"). Lake Bourget results were acquired due to a grant from the CNRS as part of the ECLIPSE and ARTEMIS National Programs. The authors also express their sincere thanks to Tomasz Goslar (Poznan, Poland) for radiocarbon dating and to John Olsen for his help with the English language. This manuscript benefited greatly from comments by anonymous referees.

\section{References}

Arnaud et al., 2005 F. Arnaud, M. Revel, E. Chapron, M. Desmet and N. Tribovillard, 7200 years of Rhône River flooding activity in Lake Bourget, France: A High-resolution sediment record of NW Alps hydrology. The Holocene, 15 (2005), pp. 420-428.

Barbe et al., 1979 Barbe, J., Faessel, B., Lafont, M., Monnot, A., Mouthon, J., Vergon, J.P., Verneaux, J., 1979. Etude écologique des lacs de Saint-Point et Remoray. Service Régional d'Aménagement des Eaux Report..

Barclay et al., 2009 D.J. Barclay, G.C. Wiles and P.E. Calkin, Tree-ring crossdates for a First Millennium AD advance of Tebenkof Glacier, southern Alaska. Quaternary

Research, 71 (2009), pp. 22-26.

Bard et al., 2000 E. Bard, G. Raisbeck, F. Yiou and J. Jouzel, Solar irradiance during the last 1200 years based on cosmogenic nuclides. Tellus, 52B (2000), pp. 985-992.

Bork, 1989 H.R. Bork, Soil erosion during the past millennium in central Europe and its significance within the geomorphodynamics of the Holocene. Catena.

Supplement, 15 (1989), pp. 121-131. 
Casty et al., 2005 C. Casty, H. Wanner, J. Luterbacher, J. Esper and R. Boehm, Temperature and precipitation variability in the European Alps since AD 1500. International Journal of Climatology, 25 (2005), pp. 1855-1880.

Chapron et al., 1999 E. Chapron, C. Beck, M. Pourchet and J.-F. Deconinck, 1822 earthquake-triggered homogenite in Lake Le Bourget (NW Alps). Terra Nova, 11 (1999), pp. 86-92.

Chapron et al., 2002 E. Chapron, M. Desmet, T. De Putter, M.F. Loutre, C. Beck and J.F. Deconinck, Climatic variability in the northwestern Alps, France, as evidenced by 600 years of terrigenous sedimentation in Lake Le Bourget. The Holocene, 12 (2002), pp. 59-68.

Castellano, 2005 E. Castellano, et al. Holocene volcanic history as recorded in the sulfate stratigraphy of the European Project for Ice Coring in Antarctica Dome CV (EDC96) ice core. Journal of Geophysical Research, 110 (2005), p. DO6114.

De Vleeschouwer et al., 2009 F. De Vleeschouwer, N. Piotrowska, J. Sikorski, J. Pawlyta, A. Cheburkin, G. Le Roux, M. Lamentowicz, N. Fagel and D. Mauquoy, Multiproxy evidence of 'Little Ice Age' palaeoenvironmental changes in a peat bog from northern Poland. The Holocene, 19 (2009), pp. 625-637.

Crowley, 2000 T.J. Crowley, Causes of climate change over the past 1000 years. Science, 289 (2000), pp. 270-277.

Giguet-Covex et al., 2009 Giguet-Covex, C., Arnaud, F., Poulenard, J., Enters, D., Reyss, J.L., Vidal, O., 2009. Multi-proxy reconstruction of trophic state and hypolimnetic anoxia in a large hard-water lake (Lake Bourget, French Alps) over the past 140 years. Journal of Paleolimnology. (Electronic publication ahead of print). doi:10.1007/S10933-009-9324-9..

Goslar et al., 2005 T. Goslar, W.O. van der Knaap, S. Hicks, M. Andric, J. Czernik, E. Goslar, S. Räsänen and H. Hyötylä, Radiocarbon dating of modern peat profiles: pre- and post-bomb ${ }^{14} \mathrm{C}$ variations in the construction of age-depth models. Radiocarbon, 47 (2005), pp. 115134.

Guiot et al., 2005 J. Guiot, A. Nicault, C. Rathgeber, J.L. Edouard, F. Guibal, G. Pichard and C. Till, Last-millennium summer-temperature variations in western Europe based on proxy data. The Holocene, 15 (2005), pp. 489-500.

Haltia-Hovi et al., 2006 E. Haltia-Hovi, T. Saarinen and M. Kukkonen, A 2000-year record of solar forcing on varved lake sediment in eastern Finland. Quaternary Science Reviews, 26 (2006), pp. 678-689.

Haeberli and Holzhauser, 2003 W. Haeberli and H. Holzhauser, Alpine glacier mass changes during the past two millennia. Pages News, 11 (2003), pp. 13-15.

Holzhauser et al., 2005 H. Holzhauser, M. Magny and H. Zumbühl, Glacier and lake-level variations in west-central Europe over the last 3500 years. The Holocene, 15 (2005), pp. 789-801. 
Hughes et al., 2006 P.D.M. Hughes, A. Blundell, D.J. Charman, S. Bartlett, J.R.G. Daniell, A. Wotjatschke and F.M. Chambers, A 8500 cal. year multi-proxy climate record from a bog in eastern Newfoundland: contributions of meltwater discharge and solar forcing. Quaternary Science Reviews, 25 (2006), pp. 1208-1227.

Jacob et al., 2008 J. Jacob, J.R. Disnar, F. Arnaud, E. Chapron, M. Debret, E. Lallier, M. Desmet and M. Revel, Millet cultivation history in the French Alps as evidenced by a sedimentary molecule. Journal of Archaeological Science, 35 (2008), pp. 814-820.

Jones et al., 2001 P.D. Jones, T.J. Osborn and K.R. Briffa, The evolution of climate over the last millennium. Science, 292 (2001), pp. 662-666.

Krivova and Solanki, 2008 N.A. Krivova and S.K. Solanki, Models of solar irradiance variations: current status. Journal of Astrophysics and Astronomy, 29 (2008), pp. 151-158.

Leroux et al., 2008 A. Leroux, V. Bichet, A.V. Walter-Simonnet, M. Magny, T. Adatte, E. Gauthier and H. Richard, The Late-Glacial-Holocene sequence of Lake Saint-Point: detrital inputs as record of climate change and anthropic impact. Comptes-Rendus de l'Académie des Sciences, Paris, Géosciences, 340 (2008), pp. 883-892.

Liu et al., 2009 J. Liu, B. Wang, Q. Ding, X. Kuang, W. Soon and E. Zorita, Centennial variations of the global monsoon precipitation in the last millennium: results from ECHO-G model. Journal of Climate, 22 (2009), pp. 2356-2371.

Lund and Curry, 2006 D.C. Lund and W. Curry, Florida current surface temperature and salinity variability during the last millennium. Paleoceanography, 21 (2006), pp. 1-15.

Magnin, 1904 A. Magnin, Monographies botaniques de 74 lacs jurassiens, Klincksieck, Paris (1904).

Magny, 1998 M. Magny, Reconstruction of Holocene lake-level changes in the Jura (France): methods and results. Paläoklimaforschung, 25 (1998), pp. 67-85.

Magny, 2004 M. Magny, Holocene climatic variability as reflected by mid-European lakelevel fluctuations, and its probable impact on prehistoric human settlements. Quaternary International, 113 (2004), pp. 65-79.

Magny, 2006 M. Magny, Holocene fluctuations of lake levels in west-central Europe: methods of reconstruction, regional pattern, palaeoclimatic significance and forcing factors, Encyclopedia of Quaternary Science, 2 ,in: S. Elias, Editor, Elsevier (2006), pp. 1389-1399.

Magny and Ruffaldi, 1995 M. Magny and P. Ruffaldi, Younger Dryas and early Holocene lake-level fluctuations in the Jura Mountains, France. Boreas, 24 (1995), pp. 155-172.

Magny et al., 2008 M. Magny, E. Gauthier, B. Vannière and O. Peyron, Palaeohydrological changes and human-impact history over the last millennium recorded at Lake Joux in the Jura Mountains, Switzerland. The Holocene, 18 (2008), pp. 255-265. 
Mann et al., 1999 M.E. Mann, R.S. Bradley and M.K. Hughes, Northern Hemisphere temperatures during the past millennium: inferences, uncertainties and limitations.

Geophysical Research Letters, 26 (1999), pp. 759-762

Mann et al., 2008 M.E. Mann, Z. Zhang, M.K. Hughes, R.S. Bradley, S.K. Miller, S. Rutherford and F. Ni, Proxy-based reconstructions of hemispheric and global surface temperature variations over the last two millennia. Proceedings of National Academic Science, 105 (2008), pp. 13252-13257.

Mauquoy et al., 2002 D. Mauquoy, B. van Geel, M. Blaauw and J. van der Plicht, Evidence from northwest European bogs shows «Little Ice Age» climatic changes driven by variations in solar activity. The Holocene, 12 (2002), pp. 1-6.

Meehl et al., 2009 G.A. Meehl, J.M. Arblaster, K. Matthes, F. Sassi and H. van Loon, Amplifying the Pacific climate system response to a small 11-year solar cycle forcing.

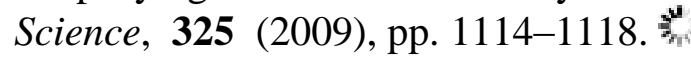

Millet et al., 2009 L. Millet, F. Arnaud, O. Heiri, M. Magny, V. Verneaux and M. Desmet, Late Holocene summer temperature reconstruction from chironomid assemblages of Lake Anterne, northern French Alps. The Holocene, 19 (2009), pp. 317-328.

Moberg et al., 2005 A. Moberg, D.M. Sonechkin, K. Holmgren, N.M. Datsenko and W. Karlén, Highly variable Northern Hemisphere temperatures reconstructed from low- and highresolution proxy data. Nature, 433 (2005), pp. 613-617

Pauling et al., 2006 A. Pauling, J. Luterbacher, C. Casty and H. Wanner, Five hundred years of gridded high-resolution precipitation reconstructions over Europe and the connection to large-scale circulation. Climate Dynamics, 26 (2006), pp. 387-405.

Reimer, 2004 P. Reimer, et al. IntCal04 terrestrial radiocarbon age calibration, 26-0 ka BP. Radiocarbon, 46 (2004), pp. 1029-1058.

Renssen et al., 2006 H. Renssen, H. Goosse and R. Muscheler, Coupled climate model simulation of Holocene cooling events: oceanic feedback amplifies solar forcing. Climate of the Past, 2 (2006), pp. 79-90.

Revel-Rolland et al., 2005 M. Revel-Rolland, F. Arnaud, E. Chapron, M. Desmet, N. Givelet, C. Alibert and M. McCulloch, $\mathrm{Sr}$ and $\mathrm{Nd}$ isotope as a tracer of sources of clastic material, in the Bourget lake sediment (NW Alps, France) during the Little Ice Age. Chemical Geology, 224-4 (2005), pp. 183-200.

Solomon et al., 2007 S. Solomon, D. Qin, M. Manning, M. Marquis, K. Averyt, M.M.B. Tignor, H. Miller, Z. Chen, Editors, Climate Change 2007: The Physical Science Basis. Contribution of Working Group I to the Fourth Assessment Report of the Intergovernmental Panel on Climate Change, Cambridge University Press, Cambridge (2007).

Stuiver et al., 1998 M. Stuiver, P.J. Reimer, E. Bard, J.W. Beck, G.S. Burr, K.A. Hughen, B. Kromer, G. McCormac, J. van der Plicht and M. Spurk, Intcal98 radiocarbon age calibration, 24 000- 0 cal BP. Radiocarbon, 40 (1998), pp. 1041-1083. 
van Geel et al., 1999 B. van Geel, O.M. Raspopov, H. Renssen, J. van der Plicht, V.A. Dergachev and H.A.J. Meijer, The role of solar forcing upon climate change. Quaternary Science Reviews, 18 (1999), pp. 331-338.

Verschuren et al., 2000 D. Verschuren, K.R. Laird and B.F. Cumming, Rainfall and drought in equatorial east Africa during the past 1100 years. Nature, 403 (2000), pp. 410-414.

Vörösmarty et al., 2000 C.J. Vörösmarty, P. Green, J. Salisbury and R.B. Lammers, Global water resources: vulnerability from climate change and population growth.

Science, 289 (2000), pp. 284-288.

Zielinski, 2000 G.A. Zielinski, Use of paleo-records in determining variability within the volcanism-climate system. Quaternary Science Reviews, 19 (2000), pp. 417-438 


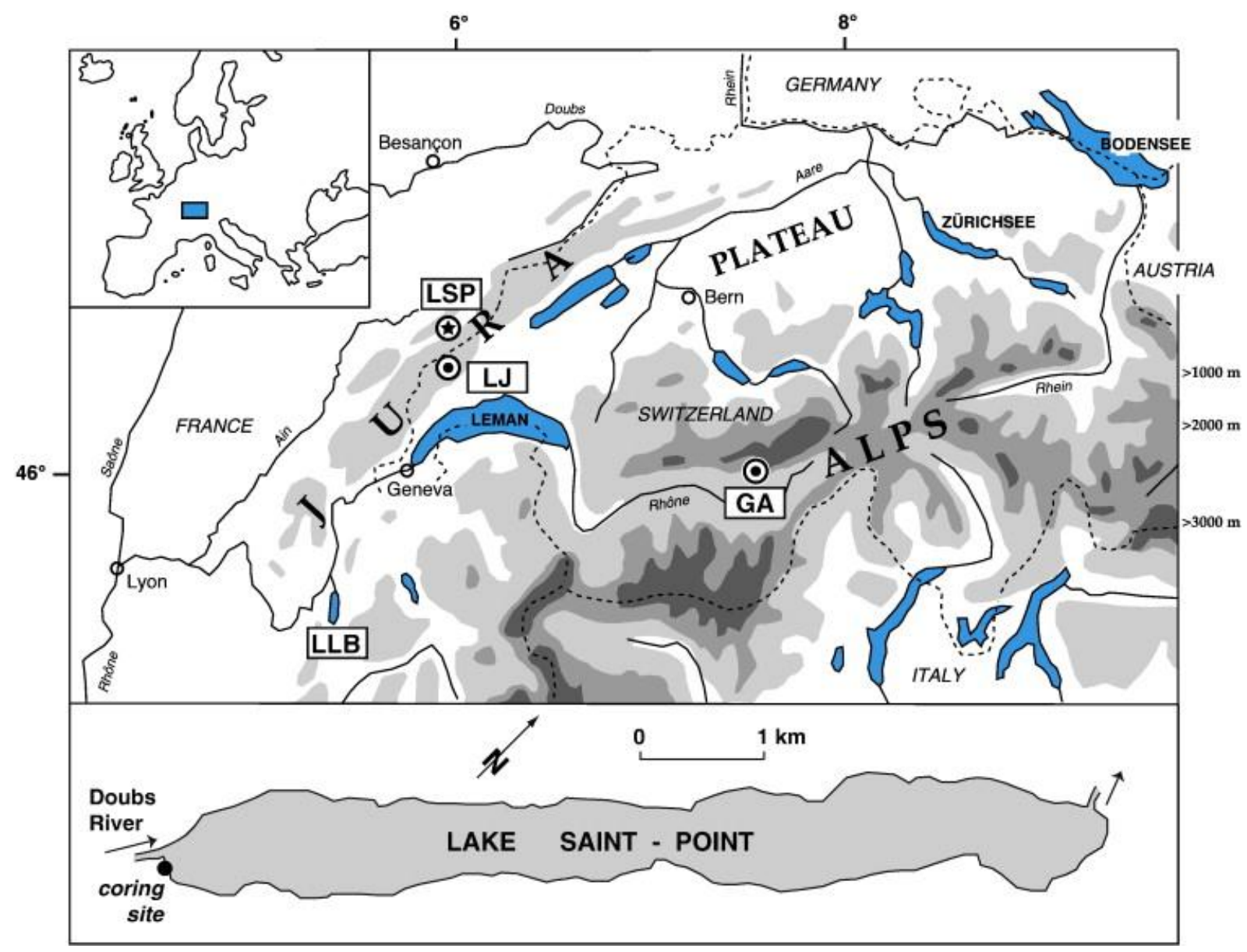

Figure 1. : Geographical location of the study site and reference sites. LSP: Lake Saint-Point; LJ: Lake Joux; LLB: Lake Le Bourget; GA: Great Aletsch Glacier. 
Table 1. Radiocarbon dates obtained from the upper part of Saint-Point core 7.

\begin{tabular}{|l|l|l|l|l|}
\hline $\begin{array}{l}\text { Depth } \\
\text { (cm) }\end{array}$ & $\begin{array}{l}\text { Radiocarbon } \\
\text { date }\end{array}$ & $\begin{array}{l}\text { Calibrated age at 2 sigma } \\
\text { range (maximum probability } \\
\text { intervals) }\end{array}$ & $\begin{array}{l}\text { Laboratory } \\
\text { reference }\end{array}$ & Material \\
\hline $\begin{array}{l}9.5- \\
10.5\end{array}$ & $\begin{array}{l}117.27 \pm 0.38 \\
\text { pMC }\end{array}$ & $>$ AD 1955 & Poz-18513 & Peat \\
\hline $31-32$ & $\begin{array}{l}245 \pm 30{ }^{14} \mathrm{C} \text { yr } \\
\text { BP }\end{array}$ & $\begin{array}{l}\text { AD 1523-1951 (AD 1630-1681 } \\
\text { and AD 1763-1802) }\end{array}$ & Poz-18514 & $\begin{array}{l}\text { Charcoal + carex } \\
\text { seeds + wood }\end{array}$ \\
\hline $71.5-$ & $\begin{array}{l}350 \pm 30 ~ \\
\text { BP }\end{array}$ & $\begin{array}{l}\text { AD 1458-1635 (AD 1458-1531 } \\
\text { and AD 1537-1635) }\end{array}$ & Poz-18517 & Charcoal \\
\hline 72.5 & $\begin{array}{l}840 \pm 30 ~ \\
\text { BP }\end{array}$ & $\begin{array}{l}\text { AD 1058-1265 ( AD 1155- } \\
1265)\end{array}$ & Poz-18519 & $\begin{array}{l}\text { Charcoal + } \\
\text { wood }\end{array}$ \\
\hline $111-$ & $\begin{array}{l}3315 \pm 30 ~ \\
\text { yr BP }\end{array}$ & $3631-3471$ cal yr BP & Poz-20683 & Wood \\
\hline 112 & & & & \\
\hline
\end{tabular}

pMC: percent modern carbon (Goslar et al., 2005). 


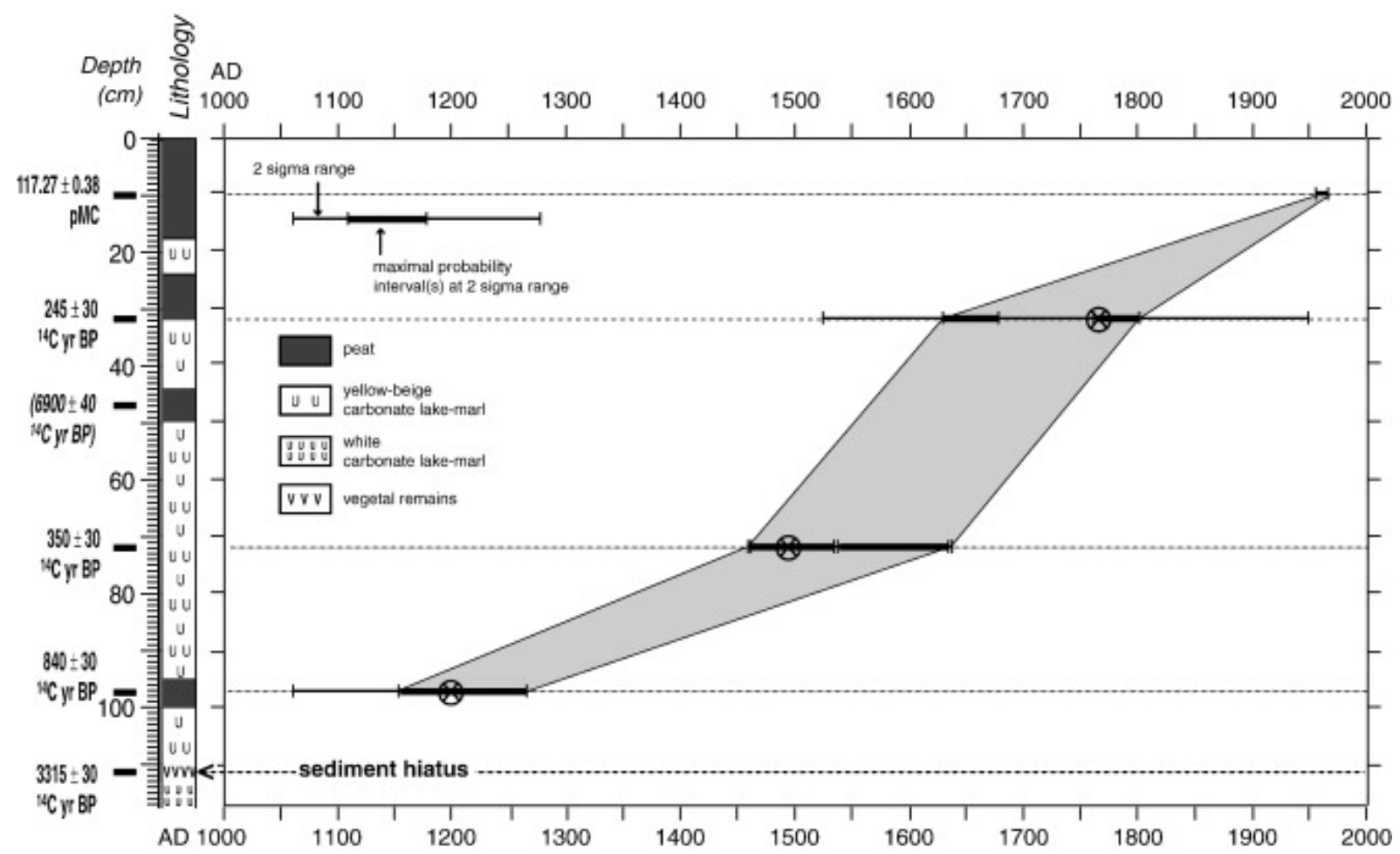

Figure 2. :Age-depth model of Saint-Point core 7. The radiocarbon ages have been calibrated and the maximum probability intervals have been defined using Calib 5.1 (Stuiver et al., 1998). Circles with cross mark the calibrated age of levels $31-32,71.5-72.5$, and $97-98 \mathrm{~cm}$ when tuning the Saint-Point lake-level record (this study) and the solar irradiance record established by Bard et al. (2000; see Fig. 4, right panel). The gray-shaded area marks the age uncertainty as defined by the maximum probability intervals at $2 \sigma$ range (see Table 1 for explanation of radiocarbon age estimates). 


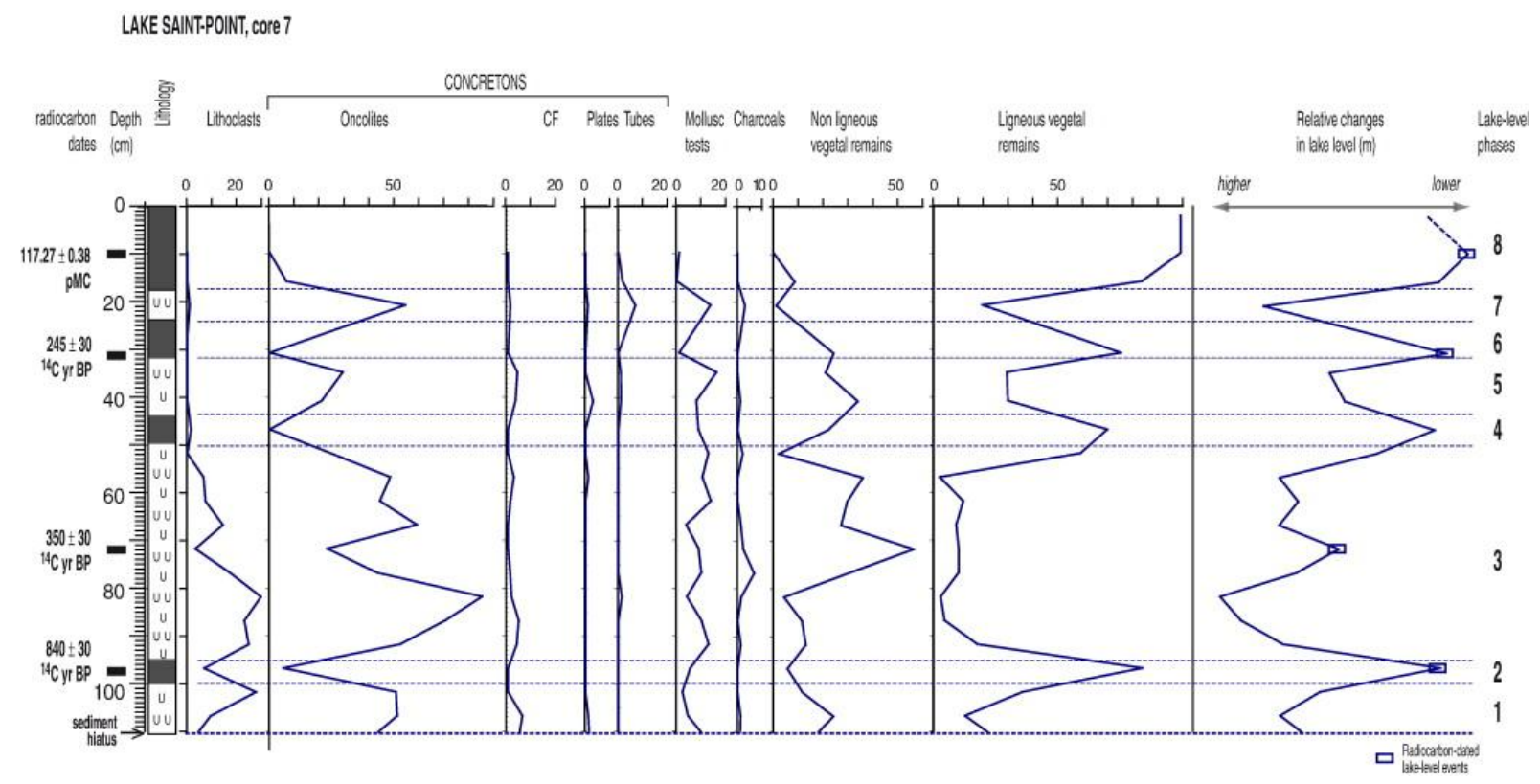

Figure 3. : Sediment diagram of Saint-Point core 7 (above level $110 \mathrm{~cm}$ ) and inferred lakelevel fluctuations for the last millennium. CF: cauliflower-like concretions. See Table 1 for explanation of radiocarbon age estimates. Rectangles on the lake-level curve indicate the radiocarbon-dated events used to tune the Saint-Point lake-level record to the solar irradiance record (see Fig. 4, right panel). 


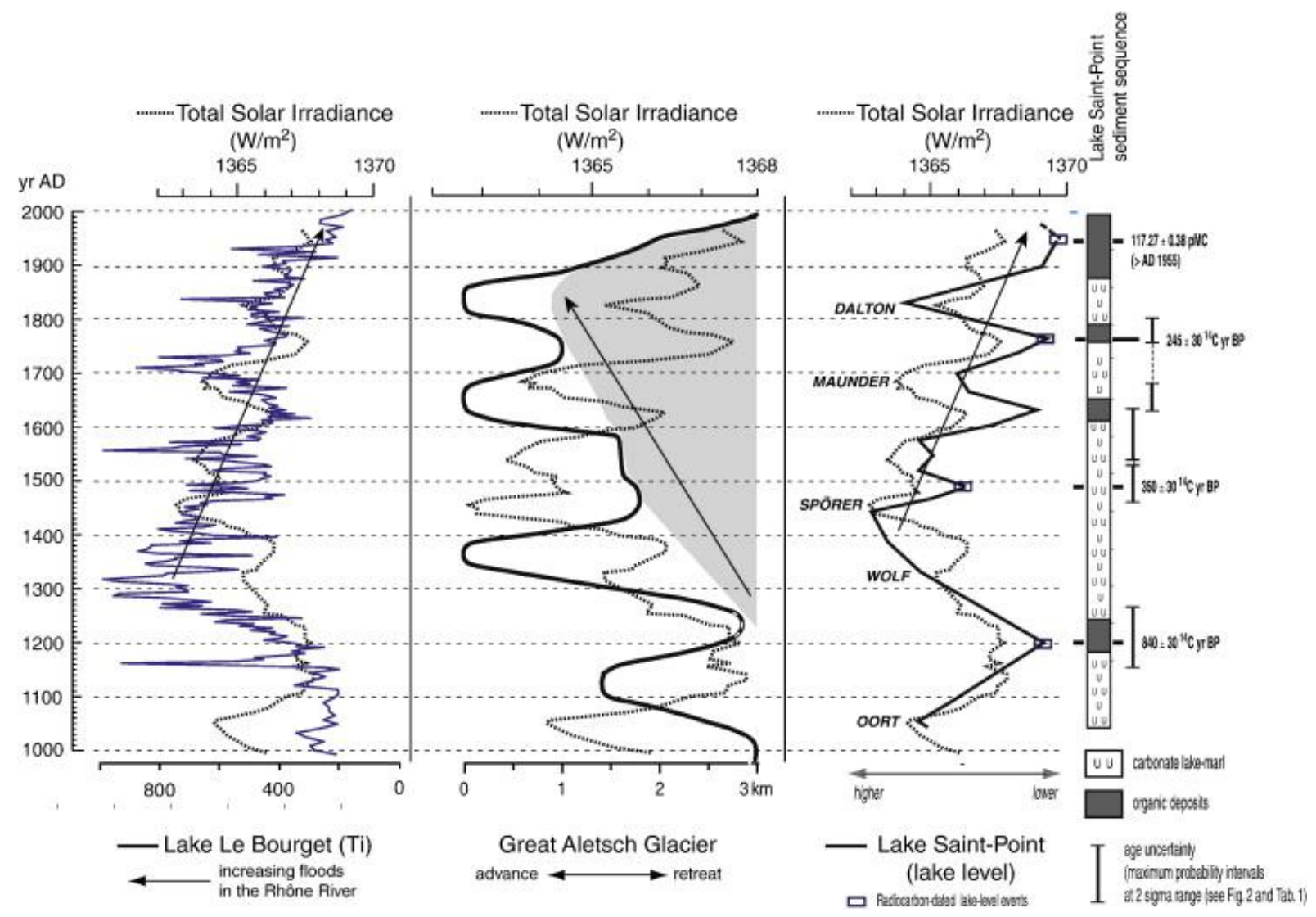

Figure 4. : Comparison over the last millennium between the Saint-Point lake-level record (this study) in the Jura Mountains, the Ti record from Lake Le Bourget in the French NW Alps (Arnaud et al., 2005), the Great Aletsch Glacier record in the Swiss Alps (Holzhauser et al., 2005), and the total solar irradiance record (Bard et al., 2000) with indication of the successive solar minimums of Oort, Wolf, Spörer, Maunder, and Dalton. The Saint-Point record has been tuned to the solar record on the basis of constraints defined by the radiocarbon dates as illustrated by Figure 2. As in Figure 3, rectangles on the lake-level curve mark the radiocarbon-dated events, while vertical bars show the age uncertainty of these events (maximal probability intervals at $2 \sigma$ range; see Fig. 2 and Table 1). The gray area suggests the cumulative effect of LIA cooling on the mass of Great Aletsch Glacier until AD 1850. The arrows point to the general trend characterizing every record over the LIA. See Table 1 for explanation of radiocarbon age estimates. 